\title{
Amendment of cattle slurry with the nitrification inhibitor dicyandiamide during storage: A new effective and practical $\mathrm{N}_{2} \mathrm{O}$ mitigation measure for landspreading
}

\author{
E.P. Minet ${ }^{\mathrm{a}, *}$, M.M.R. Jahangir ${ }^{\mathrm{a}, \mathrm{b}}$, D.J. Krol ${ }^{\mathrm{a}}$, N. Rochford ${ }^{\mathrm{a}}$, O. Fenton ${ }^{\mathrm{a}}$, D. Rooney ${ }^{\mathrm{c}}$, \\ G. Lanigan ${ }^{\mathrm{a}}$, P.J. Forrestal ${ }^{\mathrm{a}}$, C. Breslin ${ }^{\mathrm{c}}$, K.G. Richards ${ }^{\mathrm{a}, *}$ \\ ${ }^{a}$ Teagasc Environment Research Centre, Johnstown Castle, Co. Wexford, Ireland \\ ${ }^{\mathrm{b}}$ Department of Civil, Structural and Environmental Engineering, Trinity College Dublin, Dublin 2, Ireland \\ ${ }^{\mathrm{c}}$ Maynooth University, Department of Chemistry, Maynooth, Co. Kildare, Ireland
}

\section{A R T I C L E I N F O}

\section{Article history:}

Received 8 July 2015

Received in revised form 4 September 2015

Accepted 14 September 2015

Available online 25 September 2015

\section{Keywords:}

Nitrification inhibitor

Dicyandiamide

Slurry

Grassland

Nitrous oxide

Methane

\begin{abstract}
A B S T R A C T
Large quantities of organic manures and soiled water are generated by cattle housing every year. These organic wastes are stored until soil conditions are suitable for landspreading or there is a crop requirement for nutrients. After land application, some nitrogen $(\mathrm{N})$ is lost through the direct emission of nitrous oxide $\left(\mathrm{N}_{2} \mathrm{O}\right)$, a powerful greenhouse gas (GHG) produced by nitrification and partial denitrification of mineral $\mathrm{N}$. The objective of this research was to investigate whether $\mathrm{N}_{2} \mathrm{O}$ losses could be mitigated after applying cattle slurry pre-mixed with the nitrification inhibitor dicyandiamide (DCD) during anaerobic storage. Contrary to our initial hypothesis, DCD mixed with slurry did not degrade for up to six months post amendment during an incubation study. These results highlight the feasibility of amending cattle slurry with DCD directly into slurry tanks any time before land application. This incubation experiment also showed that a slow release of DCD in slurry could be achieved if the amendment used was beads of a chitosan xerogel impregnated with DCD. A field study revealed that slurry application to grassland plots can cause large $\mathrm{N}_{2} \mathrm{O}$ emissions under wet and mild conditions when ammonia emissions are expected to be low. Slurry incubated with DCD for six month was effective at significantly $(P<0.01)$ decreasing $\mathrm{N}_{2} \mathrm{O}$ net cumulative emissions, which were $88 \%$ lower than in the slurry treatment with no DCD. The addition of DCD to slurry also reduced the fraction of $\mathrm{N}_{2} \mathrm{O}$ in the total GHG net cumulative emissions from $52 \%$ down to just $10 \%$. Mixing slurry with DCD during storage could therefore offer farmers a cost-effective, practical, mitigation alternative to DCD broadcast application for the reduction of agricultural $\mathrm{N}$ losses.
\end{abstract}

(c) 2015 Elsevier B.V. All rights reserved.

\section{Introduction}

It was estimated that about 1.5 billion cattle were bred around the world in 2012 (FAO, 2014). Some of this livestock is housed for a substantial period of time each year to prevent crop and soil damage, especially in countries with a temperate climate. As a result, large quantities of organic manures and soiled water are generated and must be stored until field conditions improve, ideally being spread to coincide with a crop requirement for nutrients. In Ireland alone, an estimated 392,000 tonnes of manure nitrogen $(\mathrm{N})$ was produced in 2012 by 6.7 million dairy and non-

\footnotetext{
* Corresponding authors. Fax: +353 539142213.

E-mail addresses: eddy.minet@gmail.com (E.P. Minet), karl.richards@teagasc.ie (K.G. Richards).
}

dairy cattle (UNFCCC, 2014a), 150,218 tonnes of which were stored by farmers as liquid or solid organic manures. At the European Union (EU) scale where about 88 million cattle were raised for the dairy or beef industries in 2012, 5.8 million tonnes of $\mathrm{N}$ were generated (UNFCCC, 2014b), 3.5 million tonnes of which were stored as liquid or solid manure. When applied to soil, $\mathrm{N}$ undergoes a series of complex biochemical transformations that are necessary for plant growth but are also often accompanied by $\mathrm{N}$ losses to air and water (Fenton et al., 2009; Stark and Richards, 2008a,b). Of these $\mathrm{N}$ transformations, nitrous oxide $\left(\mathrm{N}_{2} \mathrm{O}\right)$, a powerful greenhouse gas (GHG) and a stratospheric ozone depleting substance (Ravinshakara et al., 2009), is released through nitrification and the partial denitrification of nitrate (Baggs and Philippot, 2010). In 2012 landspreading of stored cattle manures was estimated to generate about 34,649 tonnes of $\mathrm{N}_{2} \mathrm{O}-\mathrm{N} \mathrm{yr}^{-1}$ across the whole EU (UNFCCC, 2014b) with Ireland contributing 
1501 tonnes of $\mathrm{N}_{2} \mathrm{O}-\mathrm{N} \mathrm{yr}^{-1}$ (UNFCCC, 2014a). In addition to contributing to GHG direct emissions, slurry landspreading can result in other environmental impacts such as nitrate $\left(\mathrm{NO}_{3}{ }^{-}\right)$ leaching to groundwater and ammonia $\left(\mathrm{NH}_{3}\right)$ volatilisation (indirect $\mathrm{N}_{2} \mathrm{O}$ emissions).

To address increased $\mathrm{N}_{2} \mathrm{O}$ emissions from landspreading of organic animal manures, research around the world has investigated a range of emission mitigation measures (VanderZaag et al., 2011 ) including application method (Bourdin et al., 2014; Cahalan et al., 2014), application timing (Bourdin et al., 2014; Cahalan et al., 2014) and the use of nitrification inhibitors (Cahalan et al., 2014). The nitrification inhibitor dicyandiamide (DCD), a bacteriostatic and non-bactericidal agent (Amberger, 1989) has been shown to reduce both $\mathrm{NO}_{3}{ }^{-}$leaching and $\mathrm{N}_{2} \mathrm{O}$ emissions (and in various agricultural settings under temperate climatic conditions (Dennis et al., 2012; Di et al., 2007; Selbie et al., 2014; Smith et al., 2008; Watson et al., 2009; Zaman and Blennerhassett, 2010). However, few studies have investigated the effect of DCD on $\mathrm{N}_{2} \mathrm{O}$ emissions associated with the application of slurry to grassland. Recent work by Cahalan et al. (2014), where DCD was mixed with cattle slurry before land spreading (rate of DCD application between 3.8 and $10.3 \mathrm{~kg} \mathrm{ha}^{-1}$ ) has shown a $\mathrm{N}_{2} \mathrm{O}$ emission decrease of $47-70 \%$. Merino et al. (2002) sprayed DCD as a solution at a rate of $25 \mathrm{~kg} \mathrm{DCD} \mathrm{ha}^{-1}$ and reported a similar reduction in $\mathrm{N}_{2} \mathrm{O}$ losses by $60 \%$. For all its efficiency, DCD presents several shortcomings: (i) it is prone to rapid degradation in soil (Amberger, 1989; Kelliher et al., 2008) and leaching below the rooting zone (McCarty and Bremner, 1989) like many other agrichemicals, (ii) there are concerns that it might increase $\mathrm{NH}_{3}$ volatilisation in some instances despite little evidence found in the literature (Kim et al., 2012; Misselbrook et al., 2014), (iii) it is expensive (Luo et al., 2015; Zaag et al., 2011), and (iv) its transfer and persistence into milk and meat products is not well understood hence a potential problem of perception by the agricultural industry and the general public.

In New Zealand two methods of DCD delivery to grassland soil have been tested to date: DCD in suspension broadcasted to fields by contractors twice a year at a rate approximately $10 \mathrm{~kg} \mathrm{ha}^{-1} \mathrm{yr}^{-1}$ (Luo et al., 2015) or alternatively, DCD fed to livestock through feeds or drinking water. The former method provides untargeted DCD delivery to the entire grazing area and compensates for DCD losses by extending its presence in soil compared with a single application. In the latter method, which has very low toxicity for the animals (Welten et al., 2013), DCD is quantitatively excreted in urine and faeces (Ledgard et al., 2008), thus the inhibitor is delivered only to the urine patches (and dung patches to a lesser extent) at lower DCD usage rates on a per hectare basis (Luo et al., 2015; Welten et al., 2013). In the case of animal slurry, a practical and potentially cost effective (i.e. no contractor required) alternative for farmers would be to pre-mix DCD with slurry during the agitation process in storage before landspreading (inclusion of DCD in dietary amendments of cattle could also incorporate DCD in animal manures through urine and faeces excretion during housing), but the stability of DCD in animal organic wastes over time is not known. A review by McCrory and Hobbs (2001) deemed that strategy uneconomical for urease inhibitors at least, due to the need for repeated dosage to compensate for rapid breakdown. Attempts to overcome this drawback have also seen the emergence of controlled release formulations (Campos et al., 2015), whereby active agrochemical compounds are encapsulated in a slow release matrix. In that respect, a study by Minet et al. (2013) reported that in theory DCD could be sustained with a slow-release xerogel of chitosan. Chitosan is a non-toxic, biodegradable polymer formed from by the partial deacetylation of chitin. Chitin is estimated to be the second most abundant carbohydrate on the planet and is a waste product of crustacean farming making it a cheap, renewable resource. Chitosan-based materials have shown promise in a range of potential agriculture commercial products (Sharp, 2013), including seed coatings, plant protectors against pests, plant growth promoters, soil amenders. In controlled release formulations, it is has recently been predicted that chitosan-based products will be soon commonly used in agriculture (Sharp, 2013).

The general objective of this research was to test the storage of anaerobic cattle slurry pre-mixed with DCD as a new $\mathrm{N}_{2} \mathrm{O}$ mitigation measure for landspreading. The experiment was divided between an incubation and a field study. The incubation study explored (i) the stability of DCD in cattle slurry stored under anaerobic conditions at laboratory scale and (ii) the slow-release of DCD from a chitosan xerogel encapsulated with DCD. The field study examined the efficacy of DCD added to slurry and stored for six months on GHG emissions $\left(\mathrm{N}_{2} \mathrm{O}, \mathrm{CH}_{4}\right.$ and $\left.\mathrm{CO}_{2}\right)$ from landspreading to grassland soil.

\section{Materials and methods}

\subsection{Incubation study}

Anaerobic cattle slurry was collected at the Teagasc dairy farm in Johnstown Castle $\left(51^{\circ} 17^{\prime} 37 \mathrm{~N}, 6^{\circ} 29^{\prime} 47 \mathrm{~W}\right)$ prior to the experiment. The slurry was then diluted with deionised water so that dry matter (DM) content was 5\% (an average DM content for slurry in Irish farms), total $\mathrm{N}(\mathrm{TN})$ and $\mathrm{NH}_{4}-\mathrm{N}$ concentrations were 2.9 and $1.4 \mathrm{~g} \mathrm{~N} \mathrm{~kg}^{-1}$, respectively. A small portion of the $5 \%$ DM slurry was used to investigate DCD persistence and DCD slow-release from a xerogel of chitosan in an incubation study under controlled conditions $\left(15^{\circ} \mathrm{C}, 80 \%\right.$ humidity to minimise loss of water). The remaining 5\% DM slurry was incubated under the exact same conditions for a field experiment (see Section 2.2). The experimental units consisted of $100 \mathrm{~mL}$ plastic cups filled with $40 \mathrm{~mL}$ of the $5 \%$ DM slurry, with the lids kept loose to promote anaerobic conditions. The experimental treatments were:

1. Slurry no DCD (slurry control)

2. Slurry + DCD (slurry mixed with a DCD solution)

3. Slurry + chitosan/DCD (slurry mixed with beads of chitosan xerogel impregnated with DCD)

There were five destructive sampling times $(1,6,13,22,41$ days after treatment application) with four replicates per treatment $\times$ time combination (total of sixty units). The experiment was organised in a randomised block design (replicate as blocking factor). All experimental units were pre-incubated at $15^{\circ} \mathrm{C}$ for $24 \mathrm{~h}$ prior to treatment amendment.

The slurry + DCD treatment consisted of $1 \mathrm{~mL}$ of a $18.2 \mathrm{~g} \mathrm{~L}^{-1} \mathrm{DCD}$ solution added to slurry ( $1 \mathrm{~mL}$ of deionised water was added to the slurry no DCD and the slurry + chitosan/DCD treatments), which was then gently homogenised with a spatula. The calculated initial DCD concentration in slurry was $444 \mathrm{mg} \mathrm{L}^{-1}$. This value was chosen to match a $15 \mathrm{~kg} \mathrm{DCD} \mathrm{ha}^{-1}$ application rate (i.e. a median value for DCD studies according to Di and Cameron (2006)) if slurry is applied at a rate of $33 \mathrm{~m}^{3} \mathrm{ha}^{-1}$, the recommended agronomic rate for first cut silage in Ireland (Ryan, 2005).

The slurry + chitosan/DCD treatment consisted of the addition of xerogel beads of chitosan (diameter $<2 \mathrm{~mm}$ ) that contained DCD and that were prepared following the method described by Minet et al. (2013). In brief, beads encapsulated with DCD were (i) formed by precipitation of an acidified chitosan gelling solution into an alkaline solution of DCD, then (ii) consolidated by covalent crosslinking in a solution of glyoxal and DCD and eventually (iii) dried unwashed with excess glyoxal at room temperature. In order to approximately match the DCD input of the slurry + DCD treatment (i.e. $18.2 \mathrm{mg}$ DCD added per experimental unit), the amount of DCD encapsulated per bead of chitosan was estimated 
before the start of the experiment. This was achieved after incubating beads in acidified water for a week ( $\mathrm{pH}$ of 2.1 caused the beads to slowly swell and partly re-dissolve, allowing DCD to diffuse out (unpublished results showed that DCD did not degrade under such acidic conditions)). On that basis, 332 beads were used in each experimental unit of the slurry + chitosan/DCD treatment. The beads were placed in small nylon bags and dropped into the slurry units (empty nylon nets were added to the other two treatments) at the start of the experiment. They were then removed at each sampling time.

DCD was extracted from all three treatments and each sampling time with water (preliminary tests showed a DCD recovery of $103 \pm 1 \%$ in slurry spiked with DCD following this extraction method (results not shown)). Slurry aliquots $(10 \mathrm{~mL})$ were portioned off with disposable syringes after homogenising the content of each cup, mixed with $190 \mathrm{~mL}$ of deionised water (twenty-fold dilution), manually stirred for about $10 \mathrm{~min}$ and filtered with $0.45 \mu \mathrm{m}$ membranes (Sarstedt AG \& Co., Germany) into $2 \mathrm{~mL}$ HPLC vials (Waters Co., USA). All reagents used were of analytical grade and purchased from Sigma-Aldrich.

\subsection{Field study}

The field experiment was conducted in autumn 2013 (between October and November) at a permanent grassland field site in Southeast Ireland (Teagasc Environment Research Centre, Johnstown Castle, $52^{\circ} 18^{\prime} \mathrm{N}-6^{\circ} 30^{\prime} \mathrm{W}$ ). In Ireland, slurry is often spread in the few weeks before 15 th October (start of the closed period) after which date it is prohibited to be applied under the Nitrates Directive 91/676/EEC until 15th January (end of the closed period). In our experiment, treatments were applied on 14th October. This area of temperate climate had a mild and wet month of October (mean temperature of $12.4^{\circ} \mathrm{C}, 192.5 \mathrm{~mm}$ of precipitation) followed by a relatively colder and drier month of November $\left(7^{\circ} \mathrm{C}, 46.3 \mathrm{~mm}\right)$ (values measured at the on-site National Synoptic Weather Station) (Fig. 1).

The on-site Eutric Cambisol soil (top $10 \mathrm{~cm}$ ) had the following characteristics (Krol et al., 2015): loam texture (13.9\% clay, $33.2 \%$ silt, $52.9 \%$ sand), moderate permeability and drainage, $\mathrm{N}$ content $0.30 \%$ of dry weight, C content $3.16 \%$, organic C content $3.14 \%, \mathrm{pH}$ 5.7 , bulk density $1.16 \mathrm{~g} \mathrm{~cm}^{-3}$. The sward was predominantly perennial ryegrass (Lolium perenne L.). The study site had been harvested for silage with complete exclusion of animals for six months prior to the beginning of the experiment. For the study period volumetric soil moisture content was determined with a Theta Probe (typeML2, Delta-T-Devices, UK) in order to calculate the water-filled pore space (WFPS), which varied between 66 and
$80 \%$ (Fig. 1) (calculation based on the standard particle size density of $2.65 \mathrm{~g} \mathrm{~cm}^{-3}$ ) (Krol et al., 2015).

The $5 \%$ DM slurry used in the field study was the same slurry that was used in the incubation study (Section 2.1) and its incubation with and without DCD started at the same time as in the experiment described in Section 2.1. There were 3 soil treatments:

\section{Slurry no DCD}

2. Slurry + DCD ( $\left.18 \mathrm{~kg} \mathrm{DCD} \mathrm{ha}^{-1}\right)$

3. Untreated control

Slurry in the slurry + DCD treatment was amended with a DCD solution to achieve a concentration of $542 \mathrm{mg} \mathrm{L}^{-1}$, whereas slurry in the slurry no DCD treatment had an equivalent volume of deionised water added. The two slurries were stored in two loosely sealed containers at $15^{\circ} \mathrm{C}$ for six months prior to landspreading. The experimental design was a randomised block design with three replicates (replicate as blocking factor). Slurry in both slurry treatments was applied at a rate of $33 \mathrm{~m}^{3} \mathrm{ha}^{-1}\left(96 \mathrm{~kg} \mathrm{TNha}^{-1}\right.$, $45 \mathrm{~kg} \mathrm{NH}_{4}-\mathrm{Nha}^{-1}$ ) as a simulated bandspread application, with two lines of slurry $20 \mathrm{~cm}$ apart applied inside the pre-installed collar of gas chambers.

Gas emissions were measured using the static gas chamber method (De Klein and Harvey, 2012). Each stainless steel chamber consisted of two parts: a collar $(40 \times 40 \times 12 \mathrm{~cm})$ whose rim was fitted with neoprene foam seal and a lid $(41.5 \times 41.5 \times 10 \mathrm{~cm})$ fitted with a rubber septum for gas sampling. Collars were pushed 7$10 \mathrm{~cm}$ into the soil at the centre of $3 \times 2 \mathrm{~m}$ plots several days prior to the start of the experiment. At each sampling event lids were installed on collars (a $10 \mathrm{~kg}$ drum was placed on top to ensure a good seal), then three gas samples were collected through the rubber septa with a $20 \mathrm{~mL}$ polypropylene syringe equipped with a 25 -gauge Luer lock needle at $30 \mathrm{~min}$ intervals (0,30 and $60 \mathrm{~min}$ ). $15 \mathrm{~mL}$ samples were collected from the headspace and transferred into $12 \mathrm{~mL}$ pre-evacuated vial (Labco Ltd., UK). Gas samples were collected on fifteen occasions over 35 days to capture the $\mathrm{N}_{2} \mathrm{O}$ emission peak that can last for a month based on previous research. The first sampling occurred shortly after treatment application, followed by near-daily sampling over the following ten days (nine samples collected between Day 1 and Day 10). The sampling frequency decreased to three events between Day 11 and Day 20, and two events between Day 21 and Day 35.

\subsection{Analytical methods and calculations}

DCD water extracts (from slurry used in the incubation study or applied to grassland plots in the field study) and DCD acidified

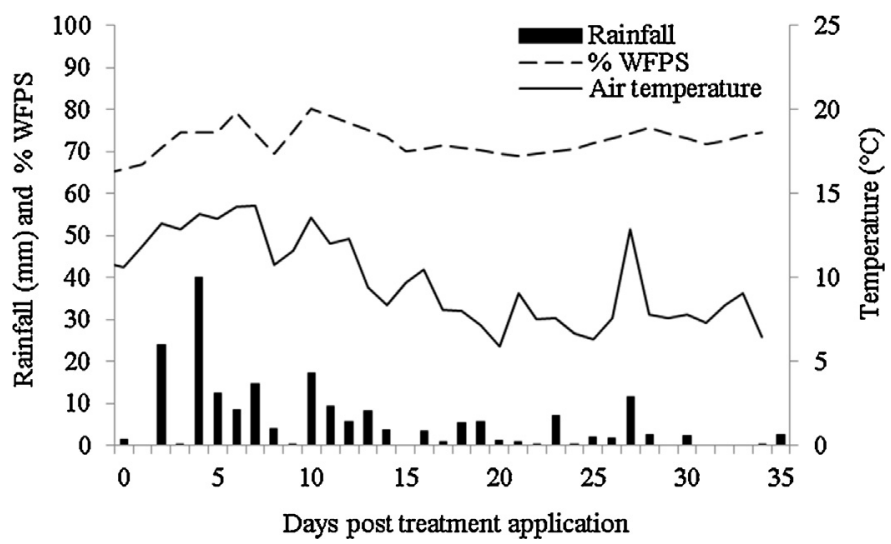

Fig. 1. Total daily precipitation ( $\mathrm{mm}$ ), mean daily temperature $\left({ }^{\circ} \mathrm{C}\right)$ and $\%$ water-filled pore space (\%WFPS) determined over the 35 day sampling period. Adapted from Krol et al. (2015). 
water extracts (from chitosan beads) were analysed by reversephase high performance liquid chromatography (HPLC) (Waters Alliance 2695 run by Empower software; Waters Co., USA) and UVvis detection (photodiode array detector Waters 996, scanning set between 190 and $300 \mathrm{~nm}$ ) according to a method by Turowski and Deshmukh (2004) (minor deviations involved UV detection at maximum DCD absorbance wavelength of $215 \mathrm{~nm}$, column temperature of $30^{\circ} \mathrm{C}$, one injection of $10 \mu \mathrm{L}$ per sample).

Gas samples were analysed with a gas chromatograph (GC) (Varian CP-3800, Varian Inc., Switzerland) equipped with a CombiPal autosampler (CTC Analytics, Zwingen, Switzerland), an electron capture detector $\left(\mathrm{N}_{2} \mathrm{O}\right.$ analysis), a flame ionisation detector (methane $\left(\mathrm{CH}_{4}\right)$ analysis) and a thermal conductivity detector (carbon dioxide $\left(\mathrm{CO}_{2}\right)$ analysis). Daily fluxes $F$ ( $\mu \mathrm{g} \mathrm{ha}^{-1}$ $\mathrm{d}^{-1}$ in Eq. (1), but expressed in $\mathrm{gha}^{-1} \mathrm{~d}^{-1}$ or $\mathrm{kgha}^{-1} \mathrm{~d}^{-1}$ in Section 3.2) were calculated for each gas and each treatment from the increase in headspace concentration over three sampling times $(0,30$ and $60 \mathrm{~min}$ after enclosure) following Eq. (1) (adapted from Kelliher et al. (2013)):

$F($ daily $)=\left(\frac{\partial C}{\partial T}\right) \times \frac{M \times P}{R \times T} \times\left(\frac{V}{A}\right)$

where $\partial C / \partial t$ is the slope of the line of best fit for the three sampling times (Saggar et al., 2007) ( $\partial C$ is the change in gas concentration in the chamber headspace during the enclosure period in ppbv or $\mu L^{-1}, \partial t$ is the enclosure period expressed in day), $M$ the molar mass of the gas element $\left(28 \mathrm{~g} \mathrm{~mol}^{-1}\right.$ for $\mathrm{N}_{2} \mathrm{O}-\mathrm{N}, 12 \mathrm{~g} \mathrm{~mol}^{-1}$ for $\mathrm{CH}_{4}-$ $\mathrm{C}$ and $\left.\mathrm{CO}_{2}-\mathrm{C}\right), P$ and $T$ the atmospheric pressure $(\mathrm{Pa})$ and temperature $(\mathrm{K})$ at the time of sampling (measured at the onsite National Synoptic Weather Station), $R$ the ideal gas constant $\left(8.314 \mathrm{~J} \mathrm{~K}^{-1} \mathrm{~mol}^{-1}\right), V$ the headspace volume of the closed chamber $\left(\mathrm{m}^{3}\right)$ and $A$ the area covered by the collar of the gas chamber (ha). The cumulative net emissions of each gas were estimated for the slurry no DCD and slurry + DCD treatments as follows: cumulative gross emissions $\left(\mathrm{kg} \mathrm{N}_{2} \mathrm{O}-\mathrm{N}, \mathrm{CH}_{4}-\mathrm{C}\right.$ or $\left.\mathrm{CO}_{2}-\mathrm{Cha}^{-1}\right)$ were calculated by trapezoidal integration for each treatment (includes the untreated control), values from the untreated control treatment were then subtracted from the two slurry treatments. Conversions for each gas were then made into $\mathrm{kg} \mathrm{CO}_{2 \mathrm{eq}} \mathrm{ha}^{-1}$ based on global warming potentials (GWP) for a 100 year time horizon $\left(\mathrm{GWP}_{\mathrm{N}_{2} \mathrm{O}}=229\right.$ and $\mathrm{GWP}_{\mathrm{CH} 4}=25$ relative to one molecule of $\mathrm{CO}_{2}$ for which $\mathrm{GWP}_{\mathrm{CO}_{2}}=1$ (IPCC, 2007) following Eq. (2):

$F$ (cumulative net, $\mathrm{kg} \mathrm{CO}_{2 \mathrm{eq}} \mathrm{ha}^{-1}$ )

$=\mathrm{GWP} \times \mathrm{F}$ (cumulative net, $\mathrm{kg} \mathrm{N}_{2} \mathrm{O}$ or $\mathrm{CH}_{4} \mathrm{ha}^{-1}$ )

Finally, emission factors $\left(\mathrm{EF}_{\mathrm{N}_{2}} \mathrm{O}\right)$ for $\mathrm{N}_{2} \mathrm{O}$ cumulative net emissions of the slurry no DCD and slurry + DCD treatments were expressed as \% of $\mathrm{N}$ applied following Eq. (3):

$\mathrm{EF}_{\mathrm{N}_{2} \mathrm{O}}=\frac{F_{\mathrm{N}_{2} \mathrm{O}}(\text { cumulative net })}{\mathrm{N} \text { applied }}$

\subsection{Statistical analysis}

In the laboratory incubation experiment (Section 3.1), the relationship between DCD concentration in slurry and incubation time was investigated for both $D C D$ treatments (slurry $+D C D$, slurry + chitosan/DCD). Significance ( 0.05 significance level) of the fitted linear regression in the slurry + DCD treatment was assessed using a distribution-free permutation test, whereas polynomial cubic curve fitting was tested for the slurry+chitosan/DCD treatment.

In the field experiment, differences in cumulative $\mathrm{N}_{2} \mathrm{O}, \mathrm{CH}_{4}, \mathrm{CO}_{2}$ and total GHG net emissions between the slurry + DCD and the slurry no DCD treatments (Section 3.3) were tested by a two-way analysis of variance (ANOVA) (treatment and replicate as independent variables). The size of the data set made it difficult to check that the model assumptions were met and therefore a distribution-free permutation test was used for the overall ANOVA test for treatment differences.

The relationships between environmental data (air temperature and \%WFPS) and daily emissions of the three gases were investigated by Spearman's rank order correlation coefficients (Section 3.4).

\section{Results}

\subsection{Incubation study}

The DCD concentration in the slurry + DCD treatment remained relatively stable around the calculated initial concentration of $444 \mathrm{mg} \mathrm{L}^{-1}$ (i.e. the value based on $33 \mathrm{~m}^{3}$ slurry applied combined with $15 \mathrm{~kg} \mathrm{DCD} \mathrm{ha}^{-1}$ ) over the 41 days of the incubation study. Variation with time (between 435 and $482 \mathrm{mg} \mathrm{L}^{-1}$ ) was not significant $(P=0.3)$ (Fig. 2$)$. In comparison, the DCD concentration in the slurry + chitosan/DCD treatment significantly increased from 240 to $606 \mathrm{mg} \mathrm{L}^{-1}$ over the incubation period in a cubic polynomial fashion $\left(R^{2}=0.999, P<0.05\right)$ (Fig. 2$)$. No DCD was ever detected in the slurry no DCD control.

\subsection{Temporal fluxes of GHG emissions post field application of slurry $\pm D C D$}

After six months of storage, DCD concentration in the slurry + DCD treatment remained elevated $\left(551 \mathrm{mg} \mathrm{L}^{-1}\right)$ and close to the initial calculated concentration $\left(542 \mathrm{mg} \mathrm{L}^{-1}\right)$. Throughout the field experiment, mean daily $\mathrm{N}_{2} \mathrm{O}-\mathrm{N}$ fluxes ranged from -1.4 to $18.0 \mathrm{~g} \mathrm{Nha}^{-1} \mathrm{~d}^{-1}$ in the untreated control, from 1.3 to $36.4 \mathrm{~g} \mathrm{~N}$ $\mathrm{ha}^{-1} \mathrm{~d}^{-1}$ in the slurry + DCD treatment and from 1.2 to $207.9 \mathrm{~g} \mathrm{~N}$ ha ${ }^{-1} \mathrm{~d}^{-1}$ in the slurry no DCD treatment (Fig. 3a). Application of the slurry no DCD treatment resulted in a sharp increase in the $\mathrm{N}_{2} \mathrm{O}-\mathrm{N}$ flux from the day of application. Values remained above the levels of the control for the next sixteen days. In contrast, application of the slurry + DCD treatment did not result in any large $\mathrm{N}_{2} \mathrm{O}-\mathrm{N}$ peak, the maximum flux being recorded at $36.4 \mathrm{~g} \mathrm{ha}^{-1} \mathrm{~d}^{-1}$ after six days and values returning to control levels after twelve days.

The daily $\mathrm{CH}_{4}-\mathrm{C}$ fluxes ranged from -5.1 to $5.0 \mathrm{~g} \mathrm{Cha}^{-1} \mathrm{~d}^{-1}$ in the untreated control, from -2.3 to $1887.8 \mathrm{gCha}^{-1} \mathrm{~d}^{-1}$ in the slurry + DCD treatment and from -6.1 to $3285.0 \mathrm{gC} \mathrm{ha}^{-1} \mathrm{~d}^{-1}$ in the

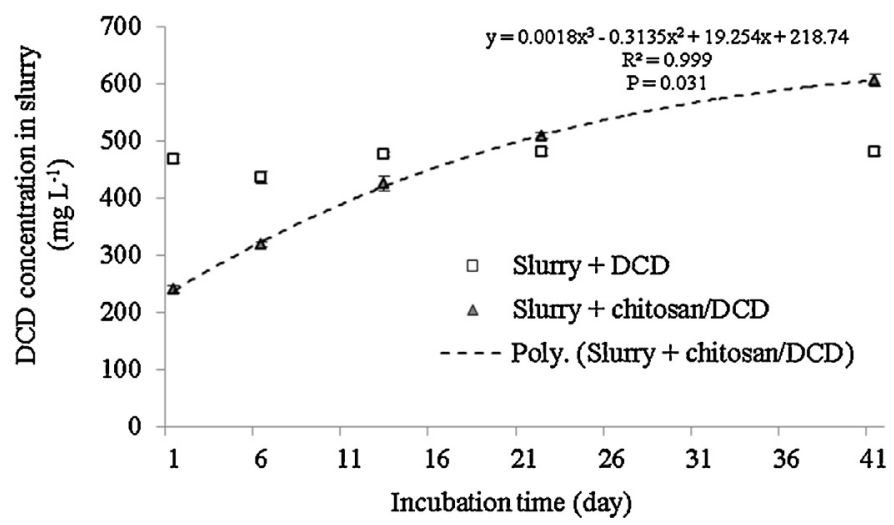

Fig. 2. Variation in DCD concentration with time ( \pm one deviation of standard error (SE), $n=4$ ) in anaerobic cattle slurry under the slurry + DCD and the slurry+ chitosan/DCD treatments (polynomial regression line and equation fitted for the slurry + chitosan/DCD treatment, no regression line for the slurry + DCD treatment because no significant relationship). 

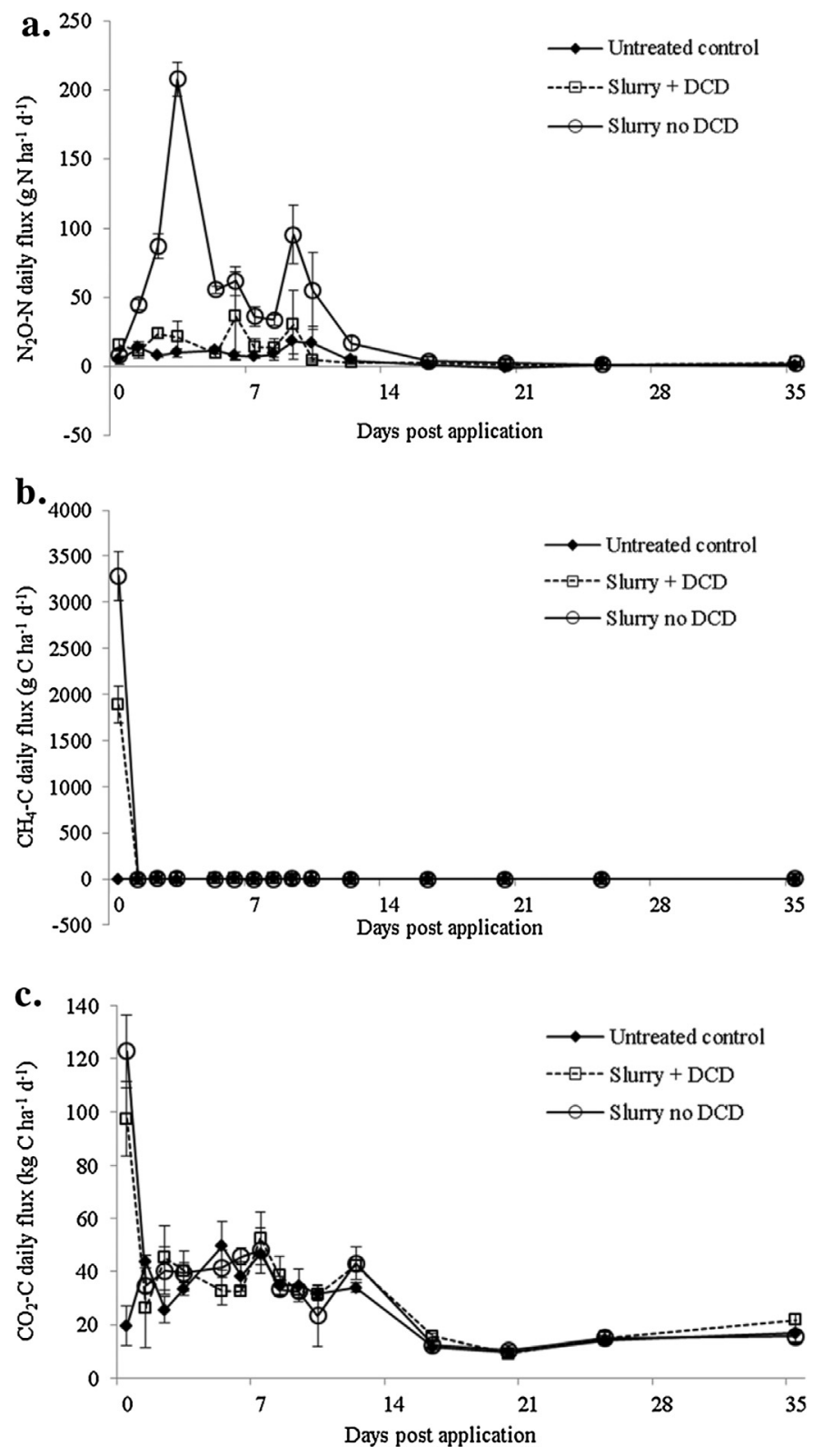

Fig. 3. Mean daily greenhouse gas fluxes (in $\mathrm{g} \mathrm{ha}^{-1} \mathrm{~d}^{-1}$ or kg ha $\mathrm{kg}^{-1} \mathrm{~d}^{-1} \pm \mathrm{SE}, n=3$ ) of (a) $\mathrm{N}_{2} \mathrm{O}-\mathrm{N}$ (b) $\mathrm{CH}_{4}-\mathrm{C}$ and (c) $\mathrm{CO}_{2}-\mathrm{C}$ from a pasture soil under three treatments: untreated control, slurry no DCD $\left(33 \mathrm{~m}^{3} \mathrm{ha}^{-1}, 96 \mathrm{~kg} \mathrm{TN} \mathrm{ha}^{-1}, 45 \mathrm{~kg} \mathrm{NH}_{4}-\mathrm{Nha}^{-1}\right)$ and slurry + DCD (15 kg DCD ha $\left.{ }^{-1}\right)$.

Table 1

Mean cumulative $\mathrm{N}_{2} \mathrm{O}, \mathrm{CH}_{4}, \mathrm{CO}_{2}$ and total GHG net emissions (each in $\mathrm{kg} \mathrm{CO}_{2 \mathrm{eq}}$ ha $^{-1}$, corrected for control values) measured over 35 days post application from a pasture soil under two treatments: slurry + DCD and slurry no DCD (\% between brackets relate to the \% of total GHG net emission).

\begin{tabular}{lllll}
\hline \multirow{2}{*}{ Treatments } & \multicolumn{4}{l}{ Cumulative net emissions $\left(\mathrm{kg} \mathrm{CO}_{2 \mathrm{eq}} \mathrm{ha}^{-1}\right)$} \\
\cline { 2 - 5 } & $\mathrm{N}_{2} \mathrm{O}$ & $\mathrm{CH}_{4}$ & $\mathrm{CO}_{2}$ & Total GHG \\
\hline Slurry+ DCD & 44.5 & 31.4 & 350.8 & 426.4 \\
Slurry no DCD & $(10 \%)$ & $(8 \%)$ & $(82 \%)$ & \\
& 371.1 & 54.5 & 288.3 & 713.8 \\
$P$ value & $(52 \%)$ & $(8 \%)$ & $(40 \%)$ & \\
SED & 0.008 & 0.1 & 0.6 & 0.15 \\
\hline
\end{tabular}

SED is the mean standard error of the difference. slurry no DCD treatment (Fig. 3b). On the day of application, values were higher in the slurry no DCD (3285.0 in $\left.\mathrm{g} \mathrm{Cha}^{-1} \mathrm{~d}^{-1}\right)$ than in slurry + DCD (1887.8 $\left.\mathrm{g} \mathrm{Cha}^{-1} \mathrm{~d}^{-1}\right)$. Within $24 \mathrm{~h}$, daily $\mathrm{CH}_{4}-\mathrm{C}$ fluxes in these two treatments dropped to the levels observed in the control and they remained low until the end of the experiment (day 35).

Daily $\mathrm{CO}_{2}-\mathrm{C}$ fluxes ranged from 9.8 to $49.6 \mathrm{~kg} \mathrm{Cha}^{-1} \mathrm{~d}^{-1}$ in the untreated control, from 9.2 to $97.4 \mathrm{~kg} \mathrm{Cha}^{-1} \mathrm{~d}^{-1}$ in the slurry + DCD treatment and from 10.5 to $122.7 \mathrm{~kg} \mathrm{Cha}^{-1} \mathrm{~d}^{-1}$ in the slurry no DCD treatment (Fig 3c). Similar to $\mathrm{CH}_{4}-\mathrm{C}, \mathrm{CO}_{2}-\mathrm{C}$ emissions were highest in the slurry no DCD and slurry + DCD treatments on the day of application, before sharply decreasing to the levels of the control until the end of the experiment.

\subsection{Cumulative fluxes of GHG emissions post field application of slurry $\pm D C D$}

The cumulative $\mathrm{N}_{2} \mathrm{O}$ gross flux from the untreated control was $18.6 \mathrm{~kg} \mathrm{CO}_{2 \mathrm{eq}} \mathrm{ha}^{-1}$. Cumulative $\mathrm{N}_{2} \mathrm{O}$ net fluxes calculated after subtracting the control were $88 \%$ lower $(P=0.008)$ in the slurry+ DCD treatment $\left(44.5 \mathrm{~kg} \mathrm{CO}_{2 \mathrm{eq}} \mathrm{ha}^{-1}\right.$ ) compared with the slurry no DCD treatment (371.1 $\mathrm{kg} \mathrm{CO}_{2 \mathrm{eq}} \mathrm{ha}^{-1}$ ) (Table 1). The $\mathrm{EF}_{\mathrm{N}_{2} \mathrm{O}}$ over the 35 day measurement period of the study were $0.83 \%$ and $0.10 \%$ for the slurry no DCD and the slurry + DCD treatments, respectively.

The cumulative $\mathrm{CH}_{4}$ gross flux from the untreated control was $-0.4 \mathrm{~kg} \mathrm{CO}_{2 \text { eq }}$ ha ${ }^{-1}$. Cumulative $\mathrm{CH}_{4}$ net fluxes calculated after subtraction of the control were entirely accounted for by the emission measured on the day of application in both slurry no DCD and slurry + DCD treatments. Net fluxes were lower in the slurry + DCD (31.4 $\left.\mathrm{kgCO}_{2 \mathrm{eq}} \mathrm{ha}^{-1}\right)$ than in the slurry no DCD treatment $\left(54.5 \mathrm{~kg} \mathrm{CO}_{2 \mathrm{eq}} \mathrm{ha}^{-1}\right.$ ), but this $42 \%$ decrease was only significant at the 0.1 level (Table 1 ).

The cumulative $\mathrm{CO}_{2}$ net flux calculated after subtraction of the control gross emission ( $2890 \mathrm{~kg} \mathrm{CO}_{2 \mathrm{eq}}$ ha $^{-1}$ ) was $22 \%$ higher in the slurry + DCD treatment $\left(350.8 \mathrm{~kg} \mathrm{CO}_{2 \mathrm{eq}} \mathrm{ha}^{-1}\right)$ than in the slurry no DCD treatment (288.3 $\left.\mathrm{kg} \mathrm{CO}_{2 \mathrm{eq}} \mathrm{ha}^{-1}\right)$, but this difference was not significant $(P=0.6)$.

The total GHG net flux calculated after subtraction of the control value $\left(2957 \mathrm{~kg} \mathrm{CO}_{2 \mathrm{eq}} \mathrm{ha}^{-1}\right)$ was $40 \%$ lower in the slurry $+\mathrm{DCD}$ treatment $\left(426.4 \mathrm{~kg} \mathrm{CO}_{2 \mathrm{eq}} \mathrm{ha}^{-1}\right)$ than in the slurry no DCD treatment $\left(713.8 \mathrm{kgCO}_{2 \mathrm{eq}} \mathrm{ha}^{-1}\right)$, but this difference was not significant $(P=0.15)$. In the slurry $+D C D$ treatment, the fraction of $\mathrm{N}_{2} \mathrm{O}$ and $\mathrm{CO}_{2}$ in the total GHG net emission were of $10 \%$ and $82 \%$, respectively (Table 1 ). In the slurry no DCD treatment however, net emissions were dominated by $\mathrm{N}_{2} \mathrm{O}(52 \%)$ and not by $\mathrm{CO}_{2}(40 \%)$. In comparison, $\mathrm{CH}_{4}$ played a minor role in both treatments $(8 \%$ of total net GHG emission).

Table 2

Spearman's rank order correlation coefficients between environmental data (air temperature and \%WFPS) and daily emissions of $\mathrm{N}_{2} \mathrm{O}-\mathrm{N}, \mathrm{CH}_{4}-\mathrm{C}$ and $\mathrm{CO}_{2}-\mathrm{C}$ in the slurry no DCD, slurry + DCD and untreated control treatments $(n=45$ for each treatment) $\left({ }^{*} P \leq 0.05,{ }^{* *} P \leq 0.01,{ }^{* * *} P \leq 0.001,{ }^{* * * *} P \leq 0.0001\right)$.

\begin{tabular}{llcc}
\hline & & Temperature $\left({ }^{\circ} \mathrm{C}\right)$ & \%WFPS \\
\hline Slurry no DCD & $\mathrm{N}_{2} \mathrm{O}-\mathrm{N}$ & $0.546^{* * * *}$ & -0.063 \\
& $\mathrm{CH}_{4}-\mathrm{C}$ & 0.236 & -0.269 \\
& $\mathrm{CO}_{2}-\mathrm{C}$ & $0.592^{* * * *}$ & 0.015 \\
& & & \\
Slurry + DCD & $\mathrm{N}_{2} \mathrm{O}-\mathrm{N}$ & $0.526^{* * *}$ & -0.181 \\
& $\mathrm{CH}_{4}-\mathrm{C}$ & -0.241 & $-0.436^{* *}$ \\
& $\mathrm{CO}_{2}-\mathrm{C}$ & $0.541^{* * *}$ & 0.026 \\
Untreated control & & & -0.059 \\
& $\mathrm{~N}_{2} \mathrm{O}-\mathrm{N}$ & $0.528^{* * *}$ & -0.111 \\
& $\mathrm{CH}_{4}-\mathrm{C}$ & 0.137 & $0.315^{*}$ \\
\hline
\end{tabular}




\subsection{Relationships between environmental data and daily emissions}

Positive and highly significant relationships $(P \leq 0.001)$ were systematically found in each treatment between air temperature and $\mathrm{N}_{2} \mathrm{O}-\mathrm{N}$ and $\mathrm{CO}_{2}-\mathrm{C}$ daily fluxes (Table 2). No significant relationship was found between air temperature and $\mathrm{CH}_{4}-\mathrm{C}$ daily fluxes. In comparison, only two significant relationships $(P \leq 0.05)$ were found between \%WFPS and daily fluxes (Table 2). $\mathrm{N}_{2} \mathrm{O}-\mathrm{N}$ and $\mathrm{CO}_{2}-\mathrm{C}$ daily fluxes were positively and significantly correlated in each treatment $(P \leq 0.001,0.49 \leq R \leq 0.712)$.

\section{Discussion}

\subsection{DCD persistence in slurry}

The stability of the DCD concentration in the slurry+ DCD treatment at the end of the six month period (Section 3.2) indicates that DCD does not degrade where slurry is stored under anaerobic conditions. The stability of DCD in anaerobically stored cattle slurry, which has never been investigated before to our knowledge, was an interesting and unexpected finding because it is well established that DCD has a limited life-span and degrades according to the first order exponential model after soil application (Kelliher et al., 2008). Nevertheless, there were a few clues that anaerobic conditions can prolong DCD persistence, although reasons for this are unclear. Amberger (1989) quoted that anaerobic soil conditions considerably slow down DCD breakdown, which was later confirmed by a rare study from Balaine et al. (2015) on the effect of soil aeration on DCD persistence. One hypothesis we make is that the concentration of metal oxides, thought to be a possible abiotic pathway that initiates DCD degradation (Amberger, 1989), will be low when oxygen is scarce. In the case of slurry stored anaerobically for a prolonged period of time, it might be the case that metal oxides levels were null (or too low) to initiate any DCD degradation. Another possible but untested explanation is that DCD breakdown is mediated by aerobic microorganisms only. Further to this, DCD can adsorb to organic matter in soil and potentially manure, but extraction tests with water showed a full recovery of DCD (Section 2.1), suggesting that adsorption of DCD may be negligible in cattle slurry. These results highlight the potential to directly add DCD to slurry tanks at the commencement of storage. However, the DCD concentration in a slurry tank spiked with DCD would need to be adjusted by dosing periodically to compensate for (i) the removal of slurry for landspreading and (ii) the addition of fresh dung and urine during animal housing, the combination of which would dilute DCD. This would not be the case where the slurry was generated by animals that were fed with DCD-amended feeds (Ledgard et al., 2008; Luo et al., 2015; Welten et al., 2013), which would result in a continuous addition of DCD to the tanks.

The literature indicates that DCD degrades quickly in soil so it was hypothesised that this might also be the case for DCD in slurry (although our finding indicates that this is not the case). To overcome the potential for DCD degradation or the need to amend with DCD over time, the novel treatment of chitosan xerogel encapsulated with DCD (slurry+chitosan/DCD treatment in Section 3.1) was included to investigate its potential as a slow release DCD delivery system. In that respect, the chitosan was successful (cubic polynomial increase in DCD concentration in Fig. 2) and it exhibited a similar DCD release profile that had been previously observed in water, where DCD concentration slowly increased with time (Minet al., 2013). DCD release from the slurry + chitosan/DCD treatment was higher than predicted in Fig. 2, most likely due to an underestimation of the total DCD bead content $\left(0.055 \pm 0.001 \mathrm{mg}\right.$ bead $^{-1}$ measured after incubation for one week in acidified water). Later tests have shown that chitosan beads should be incubated in acidified water for at least a month to extract all the encapsulated DCD. Although for the case of DCD a slow release delivery system into anaerobic slurry is not required, our findings indicate that chitosan beads do have the potential to act as delivery systems into slurry should DCD breakdown occur.

The addition of DCD to slurry during storage could present a much sought after, cost-effective and practical delivery mechanism for wide-spread adoption of $\mathrm{N}_{2} \mathrm{O}$ mitigation using nitrification inhibitors by the agricultural sector. The acceptability of using a chemical inhibitor such as DCD still requires research to understand the potential for DCD to be present in agricultural products and the persistence of DCD in the environment.

\subsection{Gas emissions trends post field application of slurry $\pm D C D$}

\subsubsection{Nitrous oxide}

The temporal $\mathrm{N}_{2} \mathrm{O}$ emission pattern of the slurry no DCD treatment (Fig. 3a) where most losses occur within three weeks of application to grassland was comparable to studies from Bourdin et al. (2014),Cahalan et al. (2014), Merino et al. (2002) and Rodhe et al. (2006). The maximum $\mathrm{N}_{2} \mathrm{O}$ daily flux in the slurry no DCD treatment occurred three days post application, similar in scale to the study by Merino et al. (2002) but higher than in other studies. These higher fluxes could be due to enhanced denitrification in anaerobic soil microsites combined with the occurrence of nitrification. Under moderate to high soil moisture (\%WFPS varied between 66 and 80\%), nitrification becomes less dominant or null, while the importance of denitrification increases towards the higher \%WFPS (Linn and Doran, 1984). The input of readily available carbon from slurry might also stimulate the latter process that is generally seen as an intrinsic larger source of $\mathrm{N}_{2} \mathrm{O}$ (Baggs and Phillipot, 2010). One might have then expected a positive relationship between \%WFPS and $\mathrm{N}_{2} \mathrm{O}$ daily emissions, but no such correlation was observed (Table 2). In addition to high soil moisture, relatively high soil temperatures during the measurement period may also have enhanced $\mathrm{N}_{2} \mathrm{O}$ emissions, which is supported by the significant positive relationships found between temperature and $\mathrm{N}_{2} \mathrm{O}$ daily emissions across all treatments (Table 2). It should be noted that this increase in $\mathrm{N}_{2} \mathrm{O}$ daily emissions was systematically accompanied by a significant increase in $\mathrm{CO}_{2}$ daily emissions. Under temperate climatic conditions, Bourdin et al. (2014) and Cahalan et al. (2014) observed a significant slurry application timing effect, with $\mathrm{N}_{2} \mathrm{O}$ emissions being elevated under warm and wetter periods. These results highlight that slurry applied to wet soil under mild temperatures can generate large $\mathrm{N}_{2} \mathrm{O}-\mathrm{N}$ daily fluxes, which could be further exacerbated if concomitant with the application of $\mathrm{N}$ fertiliser (Stevens and Laughlin, 2002), although this last aspect is outside the scope of our study. Gaseous losses from slurry are generally dominated by indirect $\mathrm{N}_{2} \mathrm{O}$ emissions that arise as a result of $\mathrm{NH}_{3}$ volatilisation (Bourdin et al., 2014), and large direct $\mathrm{N}_{2} \mathrm{O}$ emissions are generally associated with $\mathrm{N}$ fertilisers and urine patches from grazing livestock. These results, in line with Bourdin et al. (2014) or Cahalan et al. (2014), highlight that direct $\mathrm{N}_{2} \mathrm{O}$ emissions post slurry application can also become an issue.

The lower $\mathrm{N}_{2} \mathrm{O}-\mathrm{N}$ daily emissions (Fig. 3a) and cumulative net flux (Table 1) from the slurry + DCD treatment ( $88 \%$ lower than that of the slurry no DCD treatment) provided evidence that six months after amendment, DCD was still active and effectively reduced slurry $\mathrm{N}_{2} \mathrm{O}$ emissions, and that the composition of slurry had not been altered by DCD during storage in a manner that would have caused an increased $\mathrm{N}_{2} \mathrm{O}-\mathrm{N}$ flux. Such efficacy is comparable with that of a DCD solution applied directly to grassland following the application of slurry, as described by Cahalan et al. (2014) and Merino et al. (2002). This strategy of pre- 
mixing stored slurry with DCD could open up some opportunities to mitigate $\mathrm{N}_{2} \mathrm{O}$ emissions at high risk times in autumn, winter and early spring when $\mathrm{NH}_{3}$ volatilisation is lower but $\mathrm{N}_{2} \mathrm{O}$ emissions could be at their highest.

\subsubsection{Methane}

The temporal pattern of $\mathrm{CH}_{4}$ emission observed in Fig. $3 \mathrm{~b}$ for the slurry no DCD treatment (i.e. high emission on the day of application only) has previously been described by Cahalan et al. (2014) and Rodhe et al. (2006), but with lower maximum daily fluxes. This short-lived spike of $\mathrm{CH}_{4}$ is likely to originate from the rapid degassing of slurry, which could explain why daily emissions were not correlated to temperature (Table 2), as can be expected from a lengthy microbial transformation (or a chemical reaction). One cannot dismiss some soil fermentation of organic matter from the applied slurry favoured by the ephemeral anaerobic condition in the top soil as a source of $\mathrm{CH}_{4}$, although no systematic significant relationship was found between \%WFPS and $\mathrm{CH}_{4}$ daily emission (Table 2). In fact, Bourdin et al. (2014) found a $\mathrm{CH}_{4}$ emission significantly higher after a trailing shoe application than after a splash plate application, suggesting some residual methanogenesis within the band of slurry. This process should nonetheless be quickly inhibited after application since known soil methanogens are anaerobes archaea (Bodelier and Steenbergh, 2014). $\mathrm{CH}_{4}$ consumption on the other hand is an aerobic oxidising process that can be carried out by methane oxidizing bacteria (MOB), or by ammonia oxidising bacteria (AOB) and archaea (AOA) that carry the AMO gene (Bodelier and Steenbergh, 2014).

In theory, inhibiting nitrification with DCD might have also inhibited some $\mathrm{CH}_{4}$ oxidation to $\mathrm{CO}_{2}$. Yet our results did not show such a trend as the slurry + DCD treatment displayed a lower $\mathrm{CH}_{4}$ cumulative net flux than the slurry no DCD treatment (Table 1). This difference was only significant at the 0.1 significance level after field application, but it could be an indication that during storage, the incubation of slurry with DCD over a long period impaired the methanogens microflora and/or enhanced the methanotrophs. This finding is in line with other research that previously found DCD decreased $\mathrm{CH}_{4}$ emissions from anaerobic soils under rice production (Malla et al., 2005). The slightly negative cumulative flux measured in the control could suggest like others (Wulf et al., 2002) that unamended grassland soil can act as a small sink of $\mathrm{CH}_{4}$.

\subsubsection{Carbon dioxide}

The daily emissions of $\mathrm{CO}_{2}$ in Fig. $3 \mathrm{c}$ mirrored those of $\mathrm{CH}_{4}$ in Fig. 3b, with high emissions only on the day of treatment application. This was consistent with the expectation that $\mathrm{CH}_{4}$ oxidation to $\mathrm{CO}_{2}$ in the highest $\mathrm{CH}_{4}$ emitting treatment (i.e. slurry no $\mathrm{DCD}$ ) exceeds that of the lower emitting treatment (i.e. slurry + DCD). Some of the short-lived $\mathrm{CO}_{2}$ increase, not observed by Bourdin et al. (2014), might also be attributed to the hydrolysis of urea contained in slurry, which would happen within hours following application. Furthermore, slurry contains some dissolved organic carbon that is a readily available metabolite for soil microbes that can enhance soil respiration and $\mathrm{CO}_{2}$ production in the short term (Bourdin et al., 2014). On the other hand, the increased $\mathrm{CO}_{2}$ emitted might be offset by enhanced $\mathrm{CO}_{2}$ uptake from the grass during photosynthesis (Bourdin et al., 2014). It can be noted that despite the likely occurrence of a priming effect (Bol et al., 2003) soon after slurry treatments were applied, daily emissions of $\mathrm{CO}_{2}$ were positively and significantly correlated with temperature (Table 2). This result most likely reflected the expected increase in soil microbial respiration towards higher temperatures.
The lack of significant difference in cumulative $\mathrm{CO}_{2}$ net emissions between the slurry no DCD and the slurry+DCD treatments suggests that DCD did not impact microbial respiration, hence microbial biomass, as previously described by Singh et al. (2008). In fact, the cumulative gross emission for the untreated soil control was $2890 \mathrm{~kg} \mathrm{CO}_{2 \mathrm{eq}} \mathrm{ha}^{-1}$, and emissions from the two slurry \pm DCD treatments were higher by less than $400 \mathrm{CO}_{2 \mathrm{eq}} \mathrm{ha}^{-1}$ (Table 1). This finding is in line with previous studies that describes DCD as a bacteriostatic and non-bactericidal agent of low toxicity (Amberger, 1989).

\subsubsection{Total greenhouse gases (GHG)}

The cumulative total GHG gross emission (i.e. net emission from Table 1 plus background value from the untreated control) in the slurry no DCD treatment was dominated by $\mathrm{CO}_{2}$ ( $92 \%$ of total GHG), as previously observed by Bourdin et al. (2014). In the slurry + DCD treatment, total GHG gross emissions were similarly dominated by $\mathrm{CO}_{2}(87 \%)$. These results show that a large fraction of the total GHG originating largely from basal soil respiration could not be mitigated, even though DCD was effective at significantly decreasing the net emission of $\mathrm{N}_{2} \mathrm{O}$. This result could have been expected because DCD is a bacteriostatic and non-bactericidal agent (Amberger, 1989) that should not impact soil respiration.

\section{Conclusions}

Addition of nitrification inhibitors to animal organic wastes is a potential mitigation technique to reduce greenhouse gas emissions. Addition and storage of cattle slurry amended with the nitrification inhibitor DCD, via a solution addition or through DCD impregnation of chitosan beads, found that the DCD remains undegraded over a long storage period of six months. Subsequent landspreading of the stored DCD-amended slurry was an effective mitigation method to reduce emissions of $\mathrm{N}_{2} \mathrm{O}$ (and $\mathrm{CH}_{4}$ to a less extent) post application. Inclusion of chemical inhibitors to cattle slurry provides farmers with a practical and effective tool to reduce greenhouse gas emissions but there are still issues such as acceptability and public perception to be addressed.

\section{Acknowledgements}

The authors thank the Irish Department of Agriculture, Food and the Marine (Research Stimulus Fund Programme-RSF 07545), the Irish Research Council and Teagasc (Irish Research Council Enterprise Partnership Scheme Postdoctoral Fellowships program) and the INTERREG IV project BatFarm for funding this study. We also thank John Murphy and Cathal Somers (Teagasc Environment Research Centre) for their help in field/laboratory work, and Dr. Jim Grant (Teagasc Food Centre) for his help in statistical analysis. The sponsors had no other role in this study.

\section{References}

Amberger, A., 1989. Research on dicyandiamide as a nitrification inhibitor and future outlook. Commun. Soil Sci. Plant Anal. 20, 1933-1955.

Baggs, E.M., Philippot, L., 2010. Microbial terrestrial pathways to $\mathrm{N}_{2} \mathrm{O}$. In: Smith, K.A. (Ed.), Nitrous Oxide and Climate Change. Earthscan Publications, London, UK, pp. $4-35$.

Balaine, N., Clough, T.J., Kelliher, F.M., van Koten, C., 2015. Soil aeration affects the degradation rate of the nitrification inhibitor dicyandiamide. Soil Res. 53 , 137-143.

Bodelier, P.L.E., Steenbergh, A.K., 2014. Interactions between methane and the nitrogen cycle in light of climate change. Curr. Opin. Environ. Sustain. 9-10, 26-36.

Bol, R., Moering, J., Kuzyakov, Y., Amelung, W., 2003. Quantification of priming and $\mathrm{CO}_{2}$ respiration sources following slurry $\mathrm{C}$ incorporation in two grassland soils with different C content. Rapid Commun. Mass Spectrom. 17, 2585-2590. 
Bourdin, F., Sakrabani, R., Kibblewhite, M.G., Lanigan, G.J., 2014. Effect of slurry dry matter content: application technique and timing on emissions of ammonia and greenhouse gas from cattle slurry applied to grassland soils in Ireland. Agric. Ecosyst. Environ. 188, 122-133.

Cahalan, E., Ernfors, M., Müller, C., Devaney, D., Laughlin, R.J., Watson, C.J., Hennessy, D., Grant, J., Khalil, M.I., McGeough, K.L., Richards, K.G., 2014. The effect of the nitrification inhibitor dicyandiamide (DCD) on nitrous oxide and methane emissions after cattle slurry application to Irish grassland. Agric. Ecosyst. Environ. 199, 339-349.

Campos, E.V.R., de Oliveira, J.L., Fraceto, L.F., Singh, B., 2015. Polysaccharides as safer release systems for agrochemicals. Agron. Sustain. Dev. 35, 47-66.

De Klein, C.A.M., Harvey, M.J., 2012. Nitrous oxide chamber methodology guidelines. Global Research Alliance. Ministry of Primary Industries, New Zealand, pp. 146 (ISBN 978-0-478-40585-9 (online)).

Dennis, S.J., Cameron, K.C., Di, H.J., Moir, J.L., Staples, V., Sills, P., Richards, K.G., 2012. Reducing nitrate losses from grazed grassland in Ireland using a nitrification inhibitor (DCD). Biol. Environ. 1, 79-89.

Di, H.J. Cameron, K.C., 2006. Nitrous oxide emissions from two dairy pasture soils as affected by different rates of a fine particle suspension nitrification inhibitor, dicyandiamide. Biol. Fertil. Soils 42, 472-480.

Di, H.J., Cameron, K.C., Sherlock, R.R., 2007. Comparison of the effectiveness of a nitrification inhibitor dicyandiamide, in reducing nitrous oxide emissions in four different soils under different climatic and management conditions. Soil Use Manage. 23, 1-9.

FAO, 2014. http://faostat.fao.org/site/573/DesktopDefault.aspx?PageID=573\#ancor (accessed 06.07.15.).

Fenton, O., Richards, K.G., Kirwan, L., Khalil, M.I., Healy, M.G., 2009. Factors affecting nitrate distribution in shallow groundwater under a beef farm in South Eastern Ireland. J. Environ. Manage. 90, 3135-3146.

IPCC, 2007. Climate change. The Physical Science Basis-Contribution of Working Group I to the Fourth Assessment Report of the Intergovernmental Panel on Climate Change (IPCC). Cambridge University Press, Cambridge.

Kelliher, F.M., Clough, T.J., Clark, H., Rys, G., Sedcole, J.R., 2008. The temperature dependence of dicyandiamide (DCD) degradation in soils: a data synthesis. Soil Biol. Biochem. 40, 1878-1882.

Kelliher, F.M., Sherlock, R., Clough, T.J., Premaratne, M., Laughlin, R.J., McGeough, K. L., Harvey, M.J., McMillan, A.M.S., Reid, A., Saggar, S., 2013. Air sample collection, storage and analysis. In: De Klein, C.A.M., Harvey, M.J. (Eds.), Nitrous Oxide Chamber Methodology Guidelines, Version 1.0, Chapter 4, Global Research Alliance on Agricultural Greenhouse Gases. Ministry for Primary Industries, New Zealand.

Kim, D.G., Saggar, S., Roudier, P., 2012. The effect of nitrification inhibitors on soil ammonia emissions in nitrogen managed soils: a meta-analysis. Nutr. Cycl. Agroecosyst. 93, 51-64.

Krol, D.J., Forrestal, P.J., Lanigan, G.J., Richards, K.G., 2015. In situ $\mathrm{N}_{2} \mathrm{O}$ emissions are not mitigated by hippuric and benzoic acids under denitrifying conditions. Sci. Total Environ. 511, 362-368.

Ledgard, S.F., Menneer, J.C., Dexter, M.M., Kear, M.J., Lindsey, S., Peters, J.S., Pacheco, D., 2008. A novel concept to reduce nitrogen losses from grazed pastures by administering soil nitrogen process inhibitors to ruminant animals: a study with sheep. Agric. Ecosyst. Environ. 125, 148-158.

Linn, D.M., Doran, J.W., 1984. Effect of water-filled pore space on carbon dioxide and nitrous oxide production in tilled and nontilled soils. Soil Sci. Soc. Am. J. 48, 1267-1272.

Luo, J., Ledgard, S., Wise, B., Welten, B., Lindsey, S., Judge, A., Sprosen, M., 2015. Effect of dicyandiamide (DCD) delivery method, application rate, and season on pasture urine patch nitrous oxide emissions. Biol. Fertil. Soils 51, 453-464.

Malla, G., Bhatia, A., Pathak, H., Prasad, S., Jain, N., Singh, J., 2005. Mitigating nitrous oxide and methane emissions from soil under rice-wheat system with nitrification and urease inhibitors. Chemosphere 58, 141-147.

McCarty, G.W., Bremner, J.M., 1989. Laboratory evaluation of dicyandiamide as a soil nitrification inhibitor. Commun. Soil Sci. Plant Anal. 20, 2049-2065.

McCrory, D.F., Hobbs, P.J., 2001. Additives to reduce ammonia and odour emissions from livestock wastes: a review. J. Environ. Qual. 30, 345-355.

Merino, P., Estavillo, J.M., Graciolli, L.A., Pinto, M., Lacuesta, M., Muñoz-Rueda, A., Gonzalez-Murua, C., 2002. Mitigation of $\mathrm{N}_{2} \mathrm{O}$ emissions from grassland by nitrification inhibitor and Actilith $\mathrm{F}_{2}$ applied with fertilizer and cattle slurry. Soil Use Manage. 18, 135-141.
Minet, E.P., O'Carroll, C., Rooney, D., Breslin, C., McCarthy, C.P., Gallagher, L., Richards, K.G., 2013. Slow delivery of a nitrification inhibitor (dicyandiamide) to soil using a biodegradable hydrogel of chitosan. Chemosphere 93, 2854-2858.

Misselbrook, T.H., Cardenas, L.M., Camp, V., Thorman, R.E. Williams, J.R., Rollett, A.J. Chambers, B.J., 2014. An assessment of nitrification inhibitors to reduce nitrous oxide emissions from UK agriculture. Environ. Res. Lett. 9 doi:http://dx.doi.org/ 10.1088/1748-9326/9/11/115006.

Ravinshakara, A.R., Daniel, J.S., Portmann, R.W., 2009. Nitrous oxide $\left(\mathrm{N}_{2} \mathrm{O}\right)$ : the dominant ozone-depleting substance emitted in the 21st century. Science 326, 123-125.

Rodhe, L., Pell, M., Yamulki, S., 2006. Nitrous oxide: methane and ammonia emissions following slurry spreading on grassland. Soil Use Manage. 22, 229-237.

Ryan, T., 2005. Use of animal manures. Forage and Nutrition Guide 2005. Dublin IFP Media, Ireland.

Saggar, S., Hedley, C.B., Giltrap, D.L., Lambie, S.M., 2007. Measured and modelled estimates of nitrous oxide emission and methane consumption from a sheepgrazed pasture. Agric. Ecosyst. Environ. 122, 357-365.

Selbie, D.R., Cameron, K.C., Di, H.J., Moir, J.L., Lanigan, G., Richards, K.G., 2014. The effect of urinary nitrogen loading rate and DCD nitrification inhibitor on nitrous oxide emissions from an Irish grassland soil. J. Agric. Sci. 152, S159-S171.

Sharp, R.G., 2013. A review of the applications of chitin and its derivatives in agriculture to modify plant-microbial interactions and improve crop yields. Agronomy 3, 757-793.

Singh, J., Saggar, S., Giltrap, D., Bolan, N., 2008. Decomposition of dicyandiamide (DCD) in three contrasting soils and its effect on nitrous oxide emission, soi respiratory activity and microbial biomass-an incubation study. Aust. J. Soil Res. 46, 517-525.

Smith, L.C., de Klein, C.A.M., Catto, W.D., 2008. Effect of dicyandiamide applied in a granular form on nitrous oxide emissions from a grazed dairy pasture in Southland, New Zealand. N. Z. J. Agric. Res. 51, 387-396.

Stevens, R.J., Laughlin, R.J., 2002. Cattle slurry applied before fertilizer nitrate lowers nitrous oxide and dinitrogen emissions. Soil Sci. Soc. Am. J. 66, 647-652.

Stark, C.H., Richards, K.G., 2008a. The continuing challenge of nitrogen loss to the environment in the context of global change and advancing research. Dyn. Soil Dyn. Plant 2,1-12.

Stark, C.H., Richards, K.G., 2008b. The continuing challenge of nitrogen loss to the environment: environmental consequences and mitigation strategies. Dyn. Soil Dyn. Plant 2, 41-55.

Turowski, M., Deshmukh, B., 2004. Direct chromatographic method for determination of hydrogen cyanamide and dicyandiamide in aqueous solutions. Anal. Lett. 9, 1981-1989.

UNFCCC, 2014. GHG Inventories, Nation Inventory Submissions 2014. Ireland CRF doc, IRL-2014-2012. v1.4, Table 4B(b). http://unfccc.int/national_reports/ annex_i_ghg_inventories/national_inventories_submissions/items/8108php (accessed 06.07.15.)

UNFCCC, 2014. GHG Inventories, Nation Inventory Submissions 2014. European Union Convention, EUA-2014-2012. v1.3 doc, Table 4B(b). http://unfccc.int/ national_reports/annex_i_ghg_inventories/national_inventories_submissions/ items/8108php (accessed 06.07.15.).

VanderZaag, A.C., Jayasundara, S., Wagner-Riddle, C., 2011. Strategies to mitigate nitrous oxide emissions from land applied manure. Anim. Feed Sci. Tech. 166-167, 464-479.

Watson, C.J., Laughlin, R.J., McGeough, K.L., 2009. Modification of nitrogen fertilisers using inhibitors: opportunities and potentials for improving nitrogen use efficiency. Proceedings No. 658, International Fertiliser Society, York, UK, pp. 39.

Welten, B.G., Ledgard, S.F., Schipper, L.A., Waller, J.E., Kear, M.J., Dexter, M.M., 2013. Effects of prolonged oral administration of dicyandiamide to dairyheifers on excretion in urine and efficacy in soil. Agric. Ecosyst. Environ. 173, 28-36.

Wulf, S., Maeting, M., Clemens, J., 2002. Application technique and slurry cofermentation effects on ammonia, nitrous oxide, and methane emissions after spreading: II. Greenhouse gas emissions. J. Environ. Qual. 31, 1795-1801.

Zaman, M., Blennerhassett, J.D., 2010. Effects of the different rates of urease and nitrification inhibitors on gaseous emissions of ammonia and nitrous oxide, nitrate leaching and pasture production from urine patches in an intensive grazed pasture system. Agric. Ecosyst. Environ. 136, 236-246. 